\title{
PENGUJIAN KETELITIAN GEOMETRIK MESIN POTONG PELAT LOGAM DENGAN PENGARAH PISAU PARALEL DENGAN MENGGUNAKAN SNI 05-1192-1989
}

\author{
Bimbing Atedi, Djoko Agustono, H. Zainulsyah
}

\begin{abstract}
Testing of the geometrical accuracy of machine tool is one of the important factors in order to know whether the machine can produce a product that fulfills the technical requirement. A testing of shearing machine with parallelism guidance tools was conducted in this research. Testing was carried out based on SNI 05-1192-1989 about the method of testing of accuracy of shearing machine in the final state or without any load. The testing comprised of leveling, tool parallelism, guidance slot and thickness tools frame and the parallelism lower tool and faces limit. The result of the testing shows that those are some deviations which might be caused by the wear of the components. The geometrical deviation has exceeded the tolerance limit; it means that some improvement steps are needed. One of the improvement steps is re-set the machine. Another alternative is using the machine only for producing a lower accuracy product.
\end{abstract}

Key words: geometrical testing, SNI 05-1192-1989, the quality of shearing machine

\section{PENDAHULUAN}

Seiring dengan perkembangan ilmu pengetahuan dan teknologi, maka kebutuhan akan komponen-komponen dengan kepresisian tinggi semakin meningkat. Komponen-komponen tersebut sebagian dihasilkan dengan menggunakan mesin perkakas. Untuk menjamin dan meningkatkan kualitas pemotongan benda kerja hasil pemesinan, perlu diperhatikan ketelitian geometrik dari mesin perkakas, agar dapat memenuhi persyaratan standar acuan. Salah satunya adalah dengan mengacu ke dalam Standar Nasional Indonesia, SNI 05-1192-1989 yang menjelaskan tentang pengujian geometrik mesin potong pelat logam dengan pengarah pisau parallel.

Pengukuran terhadap kualitas mesin perkakas harus dilakukan secara periodik, hal ini disebabkan faktor yang mempengaruhi karakteristik mesin perkakas tersebut, seperti terjadinya keausan secara mekanik dan pengaruh dari debu atau kotoran, asap dan larutan kimia pada lingkungan pengoperasian mesin.

Untuk mengetahui penyimpangan ketelitian geometrik mesin tersebut terhadap sebuah standar, maka diperlukan pengujian. Hasil analisis pengujian dapat dijadikan pertimbangan sebagai dasar untuk pengambilan keputusan apakah perlu dilakukan usaha penggantian komponen mesin, rehabilitasi (overhaul) pada mesin atau tidak.

Mesin pemotong pelat logam termasuk jenis mesin perkakas potong yang sederhana dan dipakai untuk memotong pelat datar, mempunyai fungsi untuk membentuk suatu lembaran pelat logam menjadi pelat dengan ukuran-ukuran tertentu. Dengan adanya prosedur standar yang sudah dibakukan dalam SNI 05-1192-1989, perlu dilakukan pengujian sesuai aturan yang ditetapkan, untuk mengetahui ketelitiannya. Dengan demikian dapat diharapkan bahwa kualitas hasil pemotongan akan tetap terjaga dalam toleransi yang diijinkan.

Selain itu, untuk menjamin ketelitian dalam pengujian, alat-alat ukur penguji yang akan digunakan harus dikalibrasi terlebih dahulu. Pada tahap awal pengujian geometrik mesin, dilakukan penyelarasan (leveling), untuk menentukan bidang acuan dalam menempatkan alatalat ukur dan alat bantu yang akan digunakan.

Penelitian yang telah dilakukan, yang dibahas dalam makalah ini, bertujuan untuk mengetahui apakah mesin pemotong pelat logam yang merupakan salah satu mesin perkakas yang dimiliki oleh suatu institusi, masih memiliki ketelitian yang memenuhi persyaratan sesuai SNI. Untuk itu dilakukan pengujian sesuai SNI 05-1192-1989. Apabila ternyata hasil pengujian menunjukkan telah terjadi penyimpangan, yaitu di luar toleransi yang diijinkan, maka akan diberikan saran-saran kepada penanggungjawab mesin perkakas tersebut tentang alternatif tindakan yang bisa dilakukan agar benda kerja yang dihasilkan sesuai dengan yang diinginkan.

\section{PENGUJIAN KETELITIAN GEOMETRIK MESIN PERKAKAS}

\subsection{Macam-macam Pengujian Ketelitian Me- sin Perkakas}


Pengujian ketelitian mesin perkakas ada dua macam:

a. Pengujian Ketelitian Dinamik (Practical Test)

Pengujian ini dilakukan dengan menggunakan benda kerja uji (test workpieces) yang dikerjakan dalam kondisi finishing (under finishing condition). Dalam hal iniharus ada keseragaman dimensi dari bahan benda kerja uji antara pembuat dan pemakai.

b. Pengujian Ketelitian Statik (Geometrical Test)

Pengujian ini dilakukan tanpa pembebanan dan mesin dalam keadaan tidak bekerja. Yang harus diuji dalam hal ini adalah: dimensi, bentuk dan posisi dari setiap komponen yang berpindah relatif satu dengan yang lainnya. Pengujian ini dipusatkan pada ukuran, bentuk pemosisian, dan gerakan relatif yang berpengaruhpada ketelitian pengerjaan mesin yang diuji.

Pada umumnya pengujian mesin perkakas pertama kali dilakukan di pabrik pembuatanya. Hal ini dapat dipahami, karena pada pabrik pembuatnya tentu saja tersedia tenaga kerja yang terampil, serta peralatan uji yang mencukupi. Pembeli mesin memang biasanya juga melakukan pengujian, yang sama seperti apa yang telah dilakuka di pabrik pembuatnya. Tentu saja untuk melakukan pengujian tersebut, pembeli harus memiliki atau menyediakan peralatan uji yang diperlukan serta tenaga penguji yang memenuhi syarat. Pengujian juga bisa dilakukan dengan meminta bantuan dari institusi yang bergerak di bidang pengujian mesin perkakas.

Derajat ketelitian kerja mesin perkakas disamping tergantung pada mesinnya sendiri, juga dipengaruhi berbagai faktor lainnya, antara lain seperti:

- Tipe perkakas potong

- Pemegang perkakas potong
- Kecepatan pemotongan; pemakanan.

- Bahan yang diproses

- Bentuk, ukuran, dan kekakuan benda kerja.

- Perlengkapan pencekam.

- Keterampilan operator mesin perkakas.

Sedangkan ketelitian geometrik mesin perkakas yang langsung mempengaruhi kualitas benda kerja adalah:

- Ketelitian permukaan referensi

- Ketelitian gerak linier

- Ketelitian putaran spindel

- Ketelitian gerak pindah.

\subsection{Penentuan Penyebab Ketidaktelitian/ Penyimpangan}

Beberapa penyimpangan yang ditemukan dari hasil pengujian ketelitian mesin perkakas perlu diatasi, dengan jalan melakukan perbaikan atau penyetelan pada beberapa komponen mesin tersebut. Oleh karenanya suatu teknik atau metode untuk menentukan penyebab penyimpangan yang terjadi sangat diperlukan dan didapat melalui pengalaman dan analisa teoritis.

\section{MESIN POTONG PELAT LOGAM DENGAN PENGARAH PISAU PARALEL}

Obyek pengujian, yaitu mesin pemotong pelat logam dengan pengarah pisau paralel yang akan dibahas dalam makalah ini, mempunyai spesifikasi teknis dan bagian-bagiannya seperti terlihat pada Gambar 1

- Ketebalan pelat yang dipotong maksimum = $3 \mathrm{~mm}$

- Lebar pelat maksimum $=1200 \mathrm{~mm}$

- Power supply voltage $A C=380$ Volt, $50 \mathrm{~Hz}$ 


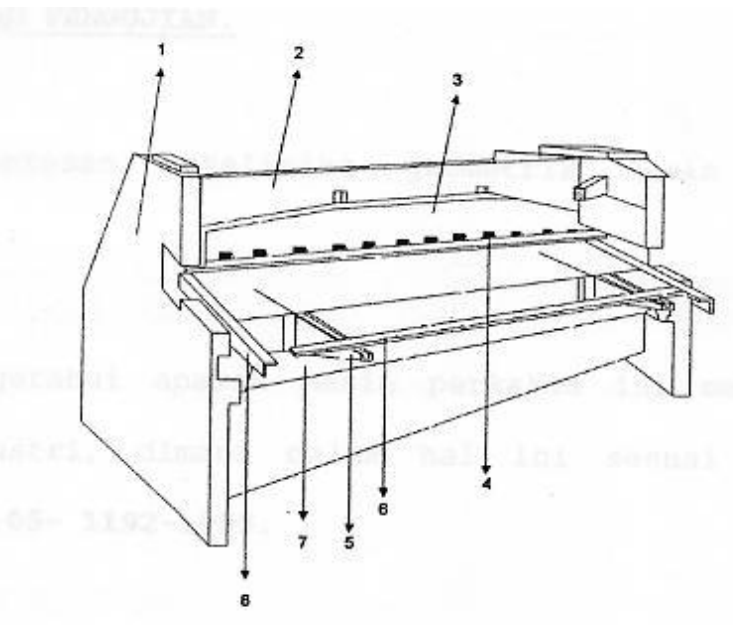

1. Kolom (column)

2 Rangka pisau (knife beam)

3 Penjepit (clamp for holding down)

4 Alat pengaman (safety device)

5 Peluas meja (table extention)

6 Pembatas muka (front stoped)

7 Meja (table)

8 Pembatas samping

Gambar 1 Mesin Potong Pelat Logam dengan Pengarah Pisau Paralel

\section{PROSEDUR DAN METODE PENGUJIAN}

Prosedur pengujian ketelitian geometrik mesin pemotong pelat logam dengan pengarah pisau paralel, didahului dengan pemeriksaan peralatan standar (alat ukur) yang akan digunakan. Alatalat ukur yang akan digunakan dalam pengujian mesin perkakas, harus sudah dikalibrasi terlebih dahulu. Beberapa tahapan yang harus dilakukan diantaranya:

- penyelarasan (leveling), dengan menempatkan bidang-bidang referensi dalam pengukuran dan perakitan komponen-komponen lainnya.

- pengkondisian temperatur

- memeriksa kebersihan dari obyek mesin, alat ukur dan alat bantunya

- memeriksa kekakuan dalam pemasangan alat-alat ukur

- memperhatikan/mencatat suasana proses pengujian
Metode pengujian ketelitian geometrik mesin potong pelat logam dengan pengarah pisau paralel dengan tinggi meja tetap dengan spindel vertikal ini dilakukan dengan berdasarkan standar acuan SNI 05-1192-1989.

Pengujian terhadap mesin mesin potong pelat logam dengan pengarah pisau paralel ini dilakukan dengan melakukan pemeriksaan pada:

\section{a. Pemeriksaan Kedudukan Mesin (Leve- ling)}

Pemeriksaan kedudukan mesin (leveling) perlu dilakukan. Tujuannya adalah untuk dapat mengetahui apakah bidang referensi dalam keadaan horisontal, sehingga pada saat operasional tidak akan terjadi puntiran (twisting). Alat ukur yang digunakan adalah pendatar mekanik (precision level) dengan kepekaan $0,05 \mathrm{~mm} / \mathrm{m}$ dan sebuah batang pelurus (straight edge). Pemeriksaan dilakukan pada posisi memanjang dan melintang seperti pada Gambar 2.
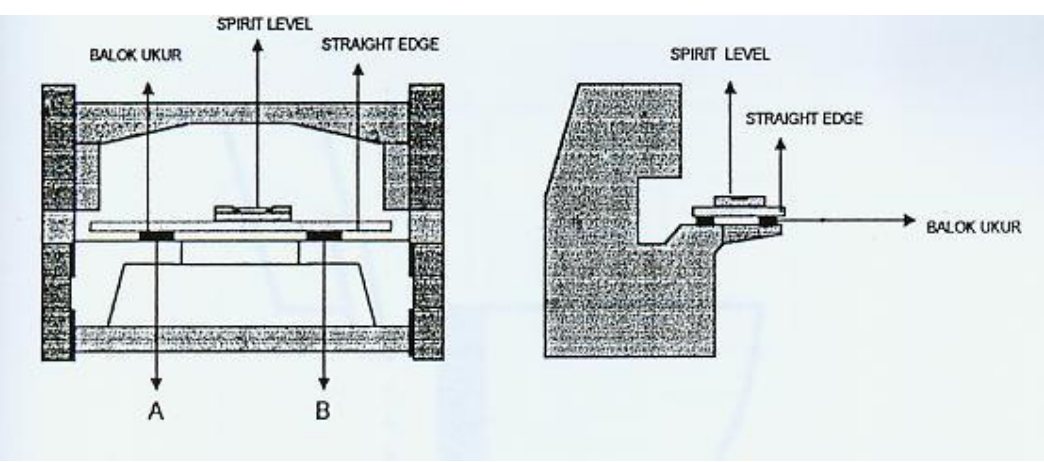

Gambar 2 Pemeriksaan Kedataran Meja Mesin 


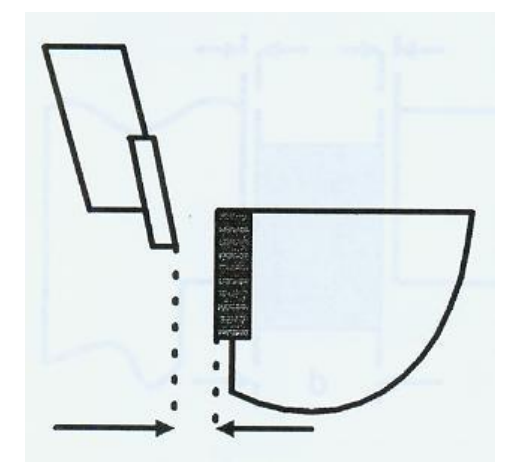

Gambar 3 Pemeriksaan Kesejajaran Mata Pisau

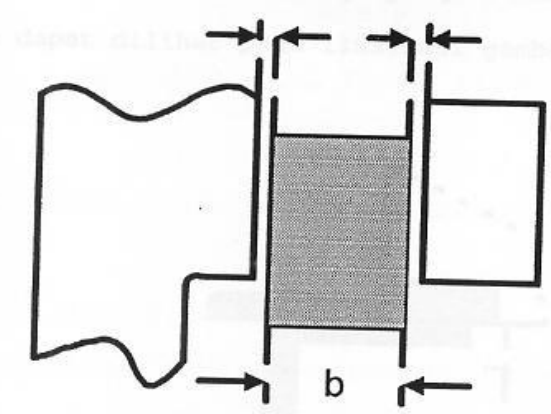

Gambar 4 Kesejajaran Alur Pengarah Rangka Pisau Ketebalan Rangka Pisau

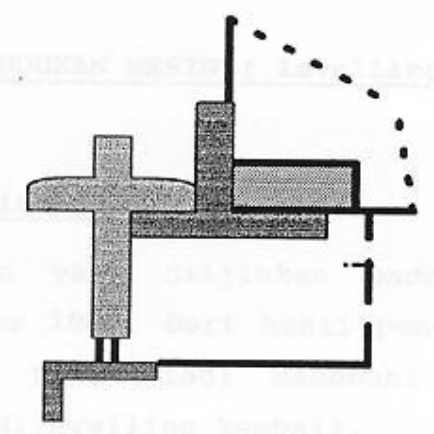

Gambar 5 Pengukuran Kesejajaran Antara Mata Pisau Bawah dan Pembatas Muka

Pada posisi memanjang caranya adalah dengan menempatkan balok ukur pada posisi A dan posisi B di atas meja mesin. Kemudian tempatkan batang pelurus sebagai dudukan pendatar mekanik di atasnya di antara posisi balok ukur seperti pada gambar, kemudian baca penyimpangannya. Demikian juga sama halnya seperti untuk posisi melintang pada gambar potongan melintang. Ulangi posisi seperti ini dan lakukan pengamatan masing-masing $3 x$ pengukuran.

\section{b. Pemeriksaan Kesejajaran Mata Pisau}

Tujuannya adalah untuk mengetahui penyimpangan celah untuk setiap jarak 150 $\mathrm{mm}$ mulai dari ujung kiri atau kanan. Pemeriksaan ini dilakukan dengan cara mengatur sedemikian rupa seingga pisau atas sedikit melewati pisau bawah. Alat ukur yang digunakan dalam pemeriksaan ini adalah pegukur celah (fillerstrip), seperti terlihat pada Gambar 3. 


\section{c. Pemeriksaan Alur Pengarah Rangka} Pisau dan Ketebalan Rangka Pisau

Tujuannya untuk mengetahui kesejajaran alur pengarah rangka pisau dan ketebalan rangkanya. Alat ukur yang digunakan adalah jenis jangka sorong kedalaman (depth caliper) dan alat pengukur celah, seperti Gambar 4

\section{d. Pengukuran Kesejajaran Antara Mata} Pisau Bawah dan Pembatas Muka

Tujuannya adalah untuk mengetahui kesejajaran antara mata pisau bawah dan pembatas muka apakah masih dalam batas toleransi yang diijinkan menurut standar SNI tersebut. Alat ukur yang dipakai adalah jangka sorong kedalaman (depth caliper).

Dalam pelaksanaan pengukuran, tempatkan pembatas muka pada jarak tertentu pada kedua sisi kiri dan kanan dan ukurkan jarak antar pisau bawah dan pembatas muka pada beberapa tempat dan hitung penyimpangan rata-ratanya. Proses pengukuran dapat dilihat pada Gambar 5

\section{HASIL PENGUJIAN DAN ANALISIS}

Luas meja pemotongan mempunyai dimensi 500 x $1200 \mathrm{~mm}$. Berdasarkan standar acuan SNI 051192-1989, penyimpangan kerataan meja pemotongan yang diijinkan adalah $0,2 \mathrm{~mm}$ per $1000 \mathrm{~mm}$, baik untuk arah memanjang dan melintang.

\subsection{Pemeriksaan Kerataan untuk Posisi Memanjang dan Melintang}

Dari hasil pengukuran untuk posisi memanjang maupun posisi melintang dari rata-rata penyimpangannya tersebut di atas, hasilnya sudah berada di luar batas toleransi yang diijinkan.

Tabel 1 Hasil Pemeriksaan Kerataan pada Posisi Memanjang

\begin{tabular}{|c|c|c|c|c|c|}
\hline $\begin{array}{c}\text { Posisi } \\
(\mathrm{mm})\end{array}$ & \multicolumn{3}{|c|}{ Penyimpangan (mm) } & $\begin{array}{c}\text { Rata-rata } \\
(\mathrm{mm})\end{array}$ & \multirow{2}{*}{$\begin{array}{c}\text { Standar SNI } \\
(\mathrm{mm})\end{array}$} \\
\cline { 2 - 5 } & $\mathrm{I}$ & $\mathrm{II}$ & $\mathrm{III}$ & \multicolumn{1}{|}{} \\
\hline 0 & 0 & 0 & 0 & 0 & \multirow{2}{*}{$0,2 \mathrm{~mm} / 1000 \mathrm{~mm}$} \\
\hline 150 & 0,35 & 0,30 & 0,25 & 0,30 & \\
\hline 300 & 0,30 & 0,35 & 0,40 & 0,35 & \\
\hline 450 & 0,30 & 0,40 & 0,45 & 0,40 & \\
\hline 600 & 0,45 & 0,35 & 0,40 & 0,40 & \\
\hline 750 & 0,55 & 0,40 & 0,40 & 0,45 & \\
\hline 900 & 040 & 0,35 & 0,30 & 0,35 & \\
\hline 1050 & 0,30 & 0,50 & 0,40 & 0,40 & \\
\hline 1200 & 0,45 & 0,35 & 0,40 & 0,40 & \\
\hline
\end{tabular}

Apabila tabel tersebut di atas digambarkan dalam bentuk grafik, maka akan terlihat sebagai berikut:

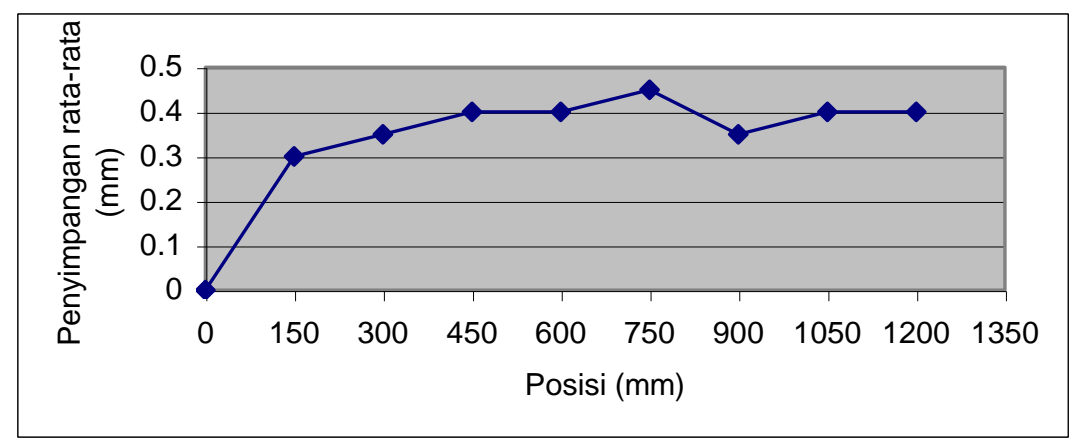


Tabel 2 Hasil Pemeriksaan Kerataan pada Posisi Melintang

\begin{tabular}{|c|c|c|c|c|c|}
\hline $\begin{array}{c}\text { Posisi } \\
(\mathrm{mm})\end{array}$ & \multicolumn{3}{|c|}{ Penyimpangan } & $\begin{array}{c}\text { Rata-rata } \\
(\mathrm{mm})\end{array}$ & $\begin{array}{c}\text { Standar SNI } \\
(\mathrm{mm})\end{array}$ \\
\cline { 2 - 5 } & $\mathrm{I}$ & $\mathrm{II}$ & $\mathrm{III}$ & & \\
\hline 0 & 0 & 0 & 0 & 0 & \\
\hline 150 & 0,20 & 0,30 & 0,25 & 0,25 & \multirow{2}{*}{$0,2 \mathrm{~mm} /$} \\
\hline 300 & 0,25 & 0,35 & 0,40 & 0,33 & \multirow{2}{*}{$1000 \mathrm{~mm}$} \\
\hline 450 & 0,25 & 0,25 & 0,30 & 0,26 & \\
\hline 600 & 0,25 & 0,35 & 0,30 & 0,30 & \\
\hline
\end{tabular}

Bila digambarkan dalam bentuk grafik, terlihat sebagai berikut:

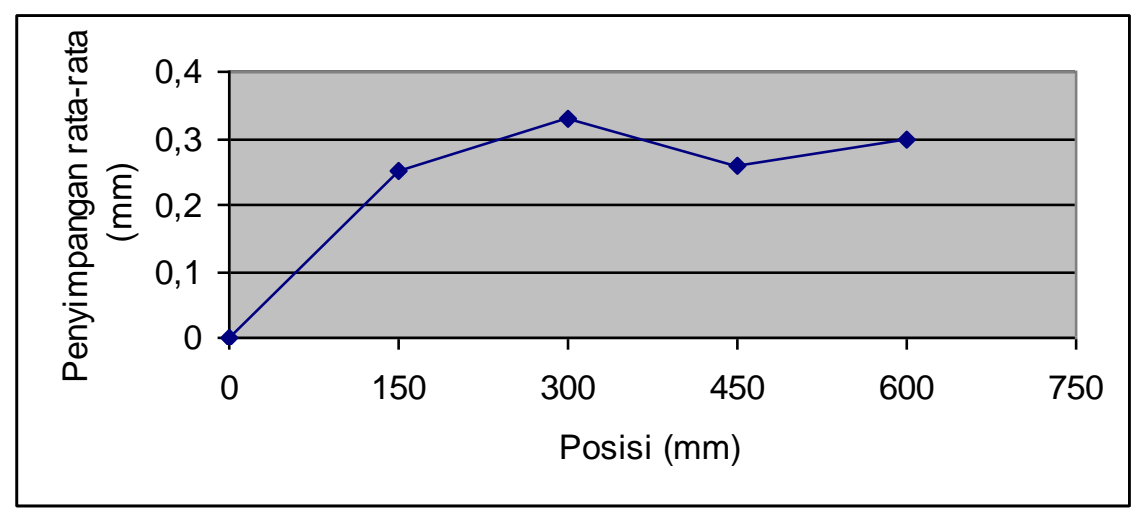

Gambar 7 Grafik Hasil Pemeriksaan Kerataan pada Posisi Melintang

\subsection{Pemeriksaan Kesejajaran Mata Pisau}

Tabel 3 Hasil Pemeriksaan Kerataan Permukaan Meja

\begin{tabular}{|c|c|c|c|c|c|}
\hline $\begin{array}{c}\text { Posisi } \\
(\mathrm{mm})\end{array}$ & \multicolumn{3}{|c|}{ Penyimpangan $(\mathrm{mm})$} & $\begin{array}{c}\text { Rata-rata } \\
(\mathrm{mm})\end{array}$ & \multirow{2}{*}{ Standar SNI (mm) } \\
\cline { 2 - 5 } & $\mathrm{I}$ & $\mathrm{II}$ & $\mathrm{II}$ & & \\
\hline 0 & 0 & 0 & 0 & 0 & \\
\hline 150 & 0,05 & 0,07 & 0,05 & 0,06 & \\
\hline 300 & 0,06 & 0,08 & 0,06 & 0,07 & \multirow{2}{*}{$0,05 \mathrm{~mm} / 1000 \mathrm{~mm}$} \\
\hline 450 & 0,06 & 0,06 & 0,08 & 0,07 & \\
\hline 600 & 0,07 & 0,08 & 0,07 & 0,07 & \\
\hline 750 & 0,05 & 0,07 & 0,05 & 0,06 & \\
\hline 900 & 0,06 & 0,06 & 0,06 & 0,06 & \\
\hline 1050 & 0,08 & 0,07 & 0,07 & 0,07 & \\
\hline 1200 & 0,06 & 0,06 & 0,05 & 0,06 & \\
\hline
\end{tabular}


Digambarkan dalam bentuk grafik:

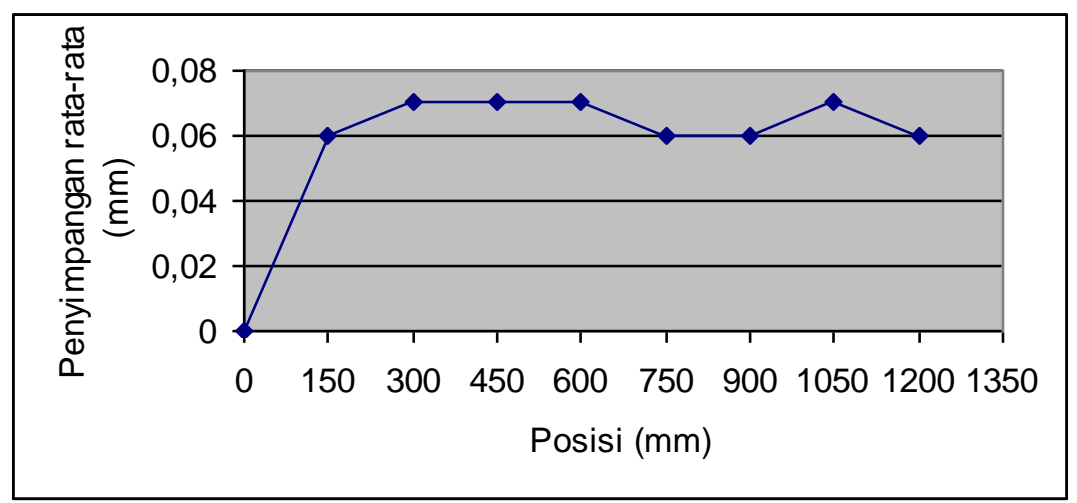

Gambar 8 Grafik Hasil Pemeriksaan Kerataan Permukaan Meja

Melihat hasil pengukuran untuk posisi memanjang maupun posisi melintang dari rata-rata penyimpangannya, sudah berada di luar batas toleransi yang diijinkan.

\subsection{Pemeriksaan Kesejajaran Alur Pengarah Rangka Pisau dan Ketebalan Rangka Pisau}

Pemeriksaan celah pada pengujian ini menggunakan alat ukur pengukur celah (fillerstrip) penyimpangan yang diijinkan menurut SNI 05-1192-1989 adalah 0,05 mm/1000mm. Hasil pe-ngamatan dari rata-rata diperoleh pada Tabel 4.

Dari hasil pengukuran untuk posisi memanjang maupun posisi melintang dari ratarata penyimpangannya, tampaklah bahwa hasilnya sudah berada di luar batas toleransi yang diijinkan.

Tabel 4 Hasil Pengukuran Alur Pengarah (a) dan Ketebalan Rangka Pisau (b)

\begin{tabular}{|c|c|c|c|}
\hline $\begin{array}{c}\text { Posisi } \\
(\mathrm{mm})\end{array}$ & $\begin{array}{c}\text { Penyimpangan pada } \\
\text { posisi a } \\
(\mathrm{mm})\end{array}$ & $\begin{array}{c}\text { Penyimpangan pada } \\
\text { posisi b } \\
(\mathrm{mm})\end{array}$ & Standar SNI (mm) \\
\hline 0 & 0,04 & 0,05 & \\
\hline 150 & 0,04 & 0,06 & \\
\hline 300 & 0,03 & 0,05 & \multirow{2}{*}{$0,05 \mathrm{~mm} /$ meter } \\
\hline 450 & 0,04 & 0,05 & \\
\hline 600 & 0,05 & 0,04 & \\
\hline 750 & 0,06 & 0,05 & \\
\hline 900 & 0,05 & 0,05 & \\
\hline 1050 & 0,04 & 0,06 & \\
\hline 1200 & 0,05 & 0,05 & \\
\hline Rata-rata & 0,05 & 0,06 & \\
\hline
\end{tabular}


Bila digambarkan dalam bentuk grafik:

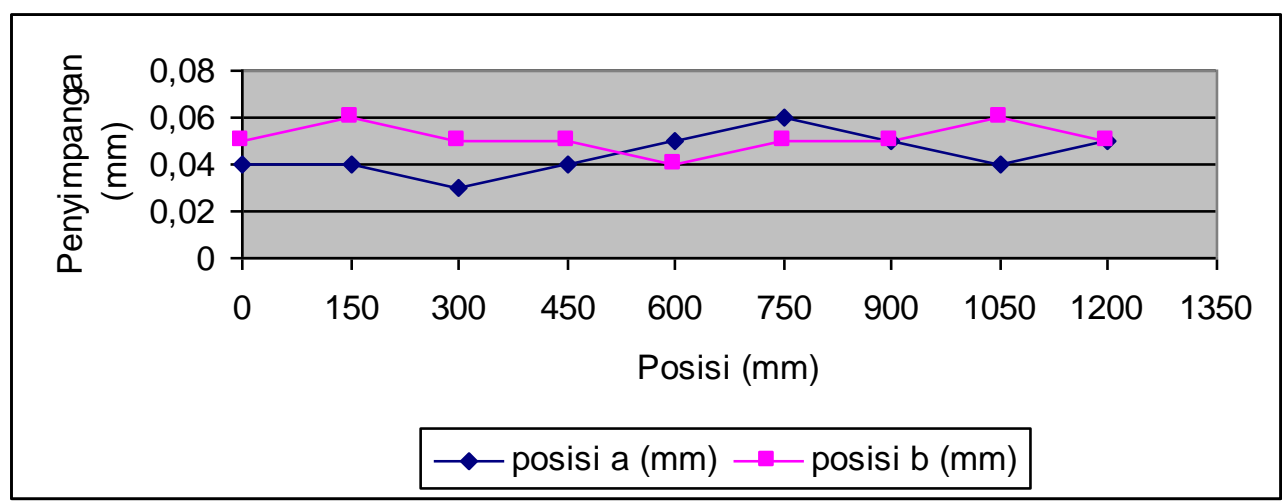

Gambar 9 Grafik Hasil Pengukuran Alur Pengarah (a) dan Ketebalan Rangka Pisau (b)

\subsection{Pemeriksaan Kesejajaran Antara Mata Pisau Bawah dan Pembatas Muka}

Pemeriksaan ini dilakukan dengan cara menempatkan pembatas muka pada jarak tertentu (i) pada kedua sisi kiri dan sisi kanan, kemudian pengukuran dilakukan antara jarak titik pisau bawah dan pembatas muka pada beberapa tempat. Menurut standar SNI tersebut penyipangan maksimum untuk pemeriksaan kesejajaran mata pisau bawah dan pembetas muka adalah sebesar $0,6 \mathrm{~mm} / 1000 \mathrm{~mm}$.

Hasil pengukuran untuk posisi memanjang maupun posisi melintang dari rata-rata penyimpangannya, sudah berada diluar batas toleransi yang diijinkan.

Tabel 5 Hasil Pengukuran Kesejajaran Antara Mata Pisau Bawah dan Pembatas Muka

\begin{tabular}{|c|c|c|}
\hline $\begin{array}{c}\text { Posisi } \\
(\mathrm{mm})\end{array}$ & $\begin{array}{c}\text { Penyimpangan Celah Antar Pisau Bawah } \\
\text { dan Pembatas Muka }(\mathrm{mm})\end{array}$ & $\begin{array}{c}\text { Standar } \\
\text { SNI }\end{array}$ \\
\hline 0 & 0,4 & \multirow{2}{*}{$0,2 \mathrm{~mm} / \mathrm{m}$} \\
\hline 150 & 0,3 & \\
\hline 300 & 0,4 & \\
\hline 450 & 0.5 & \\
\hline 600 & 0,6 & \\
\hline 750 & 0,5 & \\
\hline 900 & 0,4 & \\
\hline 1050 & 0,5 & \\
\hline 1200 & 0,6 & \\
\hline Rata-rata & 0,46 & \\
\hline
\end{tabular}


Bila digambarkan dalam bentuk grafik:

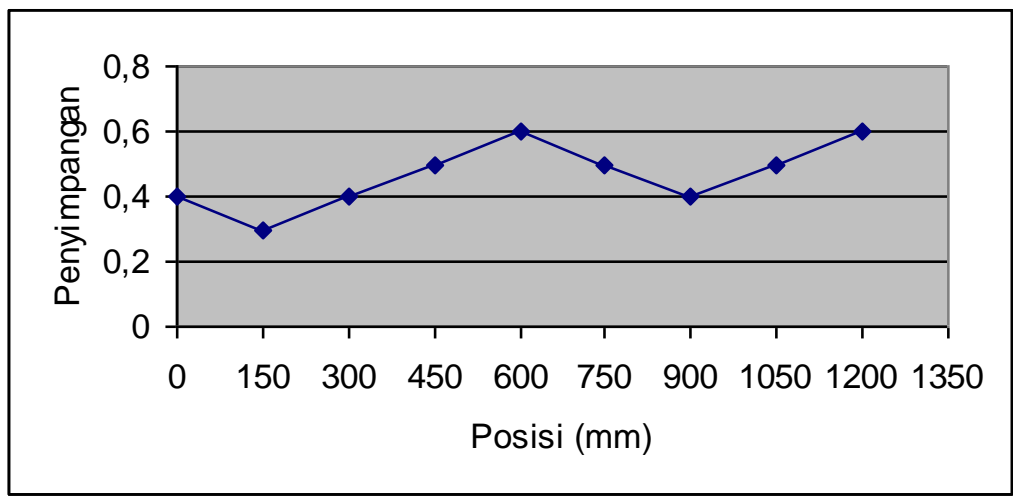

Gambar 10 Grafik Hasil Pengukuran Kesejajaran Antara Mata Pisau Bawah dan Pembatas Muka

\subsection{Penyebab Penyimpangan}

Sebagaimana telah diuraikan pada hasil pengujian di atas, maka telah terjadi penyimpangan ketelitian. Mengingat mesin yang diuji bukanlah mesin baru, maka berdasarkan pengalaman penyebab penyimpangan pada umumnya adalah telah terjadinya keausan pada beberapa komponen mesin. Secara teoritis, apabila dua buah atau lebih komponen yang saling bergesekan, maka akan terjadi keausan. Akibat keausan ini maka, sebagai contoh, pada pemeriksaan kesejajaran antara mata pisau bawah dan pembatas muka, hasilnya rata-rata $0,46 \mathrm{~mm} / \mathrm{meter}$, sedangkan berdasarkan standar hanya $0,2 \mathrm{~mm} /$ meter. Hal ini terjadi karena mata pisau dalam operasinya harus bergesekan dengan benda kerja yang akan dipotong. Penyebab penyimpangan ketelitian lainnya adalah mulai kendornya baut-baut yang digunakan.

\section{KESIMPULAN DAN SARAN}

\subsection{Kesimpulan}

Dari hasil pengujian ketelitian geometrik mesin potong pelat logam dengan pengarah rangka pisau paralel dapat disimpulkan dalam tabel sebagai berikut:

Tabel 6 Kesimpulan

\begin{tabular}{|l|l|l|l|}
\hline No & \multicolumn{1}{|c|}{ Pemeriksaan } & \multicolumn{1}{|c|}{ Standar } & \multicolumn{1}{c|}{ Hasil } \\
\hline \multirow{2}{*}{1} & Pemeriksaan kerataan mesin arah memanjang & $0,2 \mathrm{~mm} / \mathrm{m}$ & $030-0,45 \mathrm{~mm} / \mathrm{m}$ \\
\cline { 2 - 5 } & Pemeriksaan kerataan mesin arah melintang & $0,2 \mathrm{~mm} / \mathrm{m}$ & $0,20-0,35 \mathrm{~mm} / \mathrm{m}$ \\
\hline 2 & Pemeriksaan celah kesejajaran mata pisau & $0,05 \mathrm{~mm} / \mathrm{m}$ & $0,06-0,07 \mathrm{~mm} / \mathrm{m}$ \\
\hline 3 & $\begin{array}{l}\text { Pemeriksaan celah kesejajaran alur rangka pisau dan } \\
\text { ketebalan rangaknya }\end{array}$ & $0,05 \mathrm{~mm} / \mathrm{m}$ & $\begin{array}{l}0,05 \mathrm{~mm} / \mathrm{m} \mathrm{dan} \mathrm{0,06} \\
\mathrm{mm} / \mathrm{m}\end{array}$ \\
\hline \multirow{2}{*}{4} & $\begin{array}{l}\text { Pemeriksaan kesejajaran antara mata pisau dan } \\
\text { pembatas muka }\end{array}$ & $0,2 \mathrm{~mm} / \mathrm{m}$ & $0,46 \mathrm{~mm} / \mathrm{m}$ \\
\hline
\end{tabular}

- Dari keempat pengujian yang dilakukan, semuanya sudah di luar standar yang ditetapkan dalam SNI 05-1192 -1989.

- Penyimpangan toleransi tersebut terjadi karena berbagai hal, dari pengalaman selama ini, pada umumnya penyebab penyimpangan adalah karena adanya komponen-komponen yang aus, longgar, maupun berkarat. Dengan demikian mesin tersebut harus dilakukan rekondisi ulang atau overhaul, apabila diinginkan kondisinya sesuai lagi dengan SNI 05-1192-1989.

\subsection{Saran}

Mengingat hasil pengujian telah menunjukkan bahwa mesin pemotong pelat yang diuji memiliki ketelitian di bawah ketelitian yang diijinkan sebagaimana disebutkan pada SNI 05-11921989, maka perlu dilakukan langkah perbaikan/pengamanan. Untuk itu ada dua pilihan yang dapat dilakukan, yaitu:

- Melakukan penyetelan kembali komponen mesin, terutama pada kedudukan mesin (levelling). Periksa kembali komponen komponen yang ada, dan gantilah/perbaiki komponen-komponen yang sudah mengalami keausan di luar batas toleransinya, 
atau yang sudah tidak berfungsi dengan baik, misalnya berkarat.

- Pilihan ke dua adalah, dengan menggunakan mesin potong tersebut untuk memproses benda kerja yang tidak memerlukan ketelitian tinggi.

\section{DAFTAR PUSTAKA}

1. Arisandy, D., 1989. Teori Kalibrasi Mesin Perkakas, Politeknik Manufaktur Bandung, Institut Teknologi Bandung

2. ISO 230-1:1996. Test Code for Machine Tool. Geometric Accuracy of Machines Operation Under No - Load or Finishing Conditions

3. Schlesinger, G. 1978. Testing Machine Tools $8^{\text {th }}$ edition, Stockport, Cheshire, England

4. Bagiasna, K., 1986. Pengantar Pengujian Ketelitian Geometrik Mesin Perkakas, Institut Teknologi Bandung

5. SNI 05-1192-1989. Cara Uji Ketelitian Mesin Potong Pelat Logam dengan pengarah Rangka Pisau Paralel.

6. Wilson. 1992. Tools Engineers Hand-book, second Edition, American Society of Tool \& Manufacturing, McGraw-Hill

7. Rochim, Taufiq. 1985. Spesifikasi, Metrologi dan Kontrol Kualitas Geometrik, Institut Teknologi Bandung

\section{BIODATA}

Bimbing Atedi, dilahirkan di Banyumas Jawa Tengah, tanggal 21 Mei 1950. Menyelesaikan pendidikan terakhir di ISTN Jakarta, mendapatkan gelar kesarjanaan (Ir) jurusan Teknik Mesin pada tahun 1991. Saat ini penulis bekerja di Puslit - KIM LIPI Puspitek Cisauk Tangerang, menduduki jabatan fungsi-onal sebagai Peneliti Madya bidang Metrologi Dimensi, sedangkan jabatan akademis adalah Lektor Kepala di ISTN.

Djoko Agustono, dilahirkan di Bojonegoro Jawa Timur, pada tanggal 18 Agustus 1953. Menyelesaikan pendidikan kesarjanaan (Ir) Teknik Industri Unpas dan terakhir di Strathtlyte University UK (M.Sc) pada tahun 1989. Saat ini penulis bekerja di Puslit SMTP - LIPI Puspitek Cisauk Tangerang, menduduki jabatan fungsional sebagai Peneliti Madya bidang Safety and Quality, sedangkan jabatan akademis adalah Lektor Kepala di Usakti.

Zainulsyah, dilahirkan di Selat Panjang - Riau Kepulauan pada tanggal 11 April 1954. Menyelesaikan gelar kesarjanaan (Ir) Teknik Mesin Usakti pada tahun 1982, dengan pendidikan terakhir Magister Teknik (S2) jurusan Teknik Mesin UI pada tahun 1999. Saat ini penulis bekerja sebagai staf pengajar Jurusan $\mathrm{T}$. Mesin dan menduduki jabatan akademis sebagai Lektor Muda di Usakti. 